\title{
World-Wide Web as an instrument for competitive intelligence in a tertiary educational environment
}

\author{
Louis C.H. Fourie \\ Department of Business Informatics, Potchefstroom Business School, Potchefstroom \\ University for Christian Higher Education, South Africa \\ pbslchf@puknet.puk.ac.za
}

\section{Contents}

Introduction

Objective and methodology

Competitive intelligence

Using the World-Wide Web as instrument for competitive intelligence

Sources of competitive intelligence on the WWW

Practical example

Conclusions and recommendations

References

\section{Introduction}

Recent years have witnessed important developments in the tertiary educational arena in South Africa (Basson et al., 1999:13). Legislation such as the South African Qualification Authority Act (RSA, 1995), the Employment Equity Act (RSA, 1998a), the Skills Development Act (RSA, 1998b), and the Further Education and Training Act (RSA, 1998c) are impacting on the way tertiary institutions do their business. The aim of this legislation is inter alia to:

- compel business, education and training providers to redress the educational and employment inequalities of the past; and

- direct funding towards the development of skills and qualifications required in the South African workplace (Greyling, 1999:1).

This emphasis on redressing the inequalities of the past, has led to a channelling of educational funding towards previously disadvantaged groups by Government. Hence, the varying degrees of withdrawal of Government funds to tertiary educational institutions, and the increasing pressure on subsidies to tertiary institutions (Strasheim, 1998:5; Greyling, 1999:1). 
A second development that further heightens the competitiveness of the tertiary educational environment is the large influx of foreign institutions, due to the fact that South Africa is increasingly becoming part of the global arena (Greyling, 1999:2).

A third development that has impacted on the tertiary educational environment is the revolution in information technology and the resultant increase in institutions offering distance and telematic learning. Traditional geographic boundaries in tertiary education do not exist anymore. Suddenly institutions have to reckon with new fierce competition in the tertiary educational market. The problem, however, often is that, as the possibilities of the educational revolution challenge traditional business logic, it becomes clear that the current strategy and structure of tertiary institutions are woefully inadequate to meet the imminent challenges of the information age (Venkatraman \& Henderson, 1998:33).

All these developments resulted in tertiary institutions having to reposition themselves in the competitive tertiary educational market place by becoming more market oriented and client focused. Tertiary institutions now have to market their programmes and services to clients (learners and businesses). Suddenly institutions have to focus on quality and customer service in order to survive, as well as address vocational needs and workplace compentency in an ever-changing technology world (Greyling, 1999:1).

It thus becomes clear that in this new educational environment, tertiary educational institutions will have to function increasingly like a business. Because business is very much about making the right pro-active decisions based on relevant and meaningful information in an ever-changing environment, tertiary educational institutions will have to make use of competitive intelligence to position themselves in the market and to obtain a strategic competitive advantage (Fuld, 1995:1). In the world of business, knowledge is power.

\section{Objective and methodology}

The objective of this paper is therefore to determine the usefulness of the World Wide Web for competitive intelligence in the tertiary educational environment, with specific reference to curriculum development for the MBA programme at the Potchefstroom Business School.

The empirical research entails the use of competitive intelligence methods to determine the focus and core subjects of all the traditional South African business schools, as well as the most important American and European business schools. The business schools of America and Europe were selected at the hand of external evaluations and ratings of business schools. The survey was exclusively done by means of the World Wide Web (WWW).

\section{Competitive intelligence}

Competitive intelligence, also referred to as corporate or business intelligence, is an emerging discipline, which has only become increasingly important in the business arena since the early 1980s. Although its practical origins date back many decades, its intellectual origins can be attributed to Harvard professor, Michael Porter, when in 1980 he used the technique of competitive intelligence to analyse industries and competitors (McGonagle \& Vella, 1996:15). Although the gathering of competitive intelligence began in many different disciplines such as strategic planning, sales prospecting, library science, statistics, accounting, detective sleuthing and military intelligence, it has since developed into an 
A possible explanation for this emerging discipline is the so-called 'data or information explosion' characterised by the increasing availability of information itself, as reflected in the proliferation of commercial databases worldwide (Kahaner, 1996:28). Other causes of this growth is possibly the very nature of the times in which we now live - times of great worldwide political and social changes, increasing pace of business, increased global competition from new competitors, more aggressive competition, and rapid technological changes (Kahaner, 1996:28-31). Combs and Moorhead (1992) point out that never before have so many opportunities or dangers presented themselves. In fact, in an unassuming, but diligent and measured manner some multinational companies are increasingly treating business like an economic war. With ever-increasing vehemence such organisations are methodically monitoring and investigating their competitors, while deploying all the resources they have at their disposal in order to beat their current or future rivals (Hannon, 1997:82). Kahaner (1996:17) states that competitive intelligence has become the 'latest weapon in the world war of economics', where many emerging economies, view competitive intelligence as a way to win economic wars against larger, more industrialised countries. By using their wits instead of weapons, these countries are able to turn raw information into usable intelligence to further their economic status. According to Fuld (1995:23) most corporate victories result from well-designed products and services, hard-won marketing campaigns, and the strategic use of intelligence. On the other hand, most failures come from a combination of bad timing, poor judgement, and misuse, or insufficient use, of business intelligence.

Although there are many definitions of competitive intelligence, they all centre around the same critical aspects, namely the systematic selection, collection, processing, interpretation, analysis and distribution of highly specific and timely information concerning industry rivals and the external business environment, coming from a myriad of publicly held sources, which is then used to make calculated strategic business decisions, often based on predictions about the competitor's position, performance, capabilities and intentions (Fuld, 1985:5; Combs \& Moorhead, 1992; Gilad, 1994:111; Kahaner, 1996:16; Johnson, 1998).

The 1990s have brought forth various concepts and processes to make companies more competitive, for example downsizing, business process reengineering, customer-focused (or driven) organisations, total quality management, ISO9000, flatter organisations, and virtual companies. Although each one of these initiatives was an effort to make the organisation more competitive, it must be borne in mind that competition is a constantly changing process. What is thus more important for an organisation is to be able to manage change by identifying and responding to change. This of course requires intelligence (McGonagle \& Vella, 1996:5-9).

Given this changing scene, competitive intelligence is an activity of increasing importance. Whether the need is for knowledge of an industry, a market, a product or a competitor, reliable local and global information is imperative for success (Combs \& Moorhead, 1992). However, it must be pointed out that data and information, as found in a newspaper article, an annual report, or something out of a database, do not qualify as intelligence until they have been processed by a human mind that knows which questions need to be answered (Heath, 1996:1).

Owing to the discipline of competitive intelligence being so young, studies on the use of competitive intelligence in various fields are limited. It was only recently extended to human resource management (Hannon, 1997) and the stock market (De Wet, 1999).

The intention of this paper is to illustrate that competitive intelligence can also successfully be applied as a tool in the tertiary educational environment. McGonagle and Vella (1996:41) 
has already illustrated that all organisations, regardless of size, require competitive intelligence in order to survive. In the business world, knowledge is power. The ways in which institutions manage the internal and external knowledge they have about themselves and their rivals, and how they convert that knowledge into responsiveness and action in terms of their strategic plan and its tactical execution, are indicative of why institutions eventually fail or succeed (Johnson, 1998a). Those who succeed are the ones who understand their potential customers, partners, the competitor organisation's structure, culture, behaviour, capabilities and weaknesses, as well as the changing market structures, emerging technology initiatives, global economic conditions, competitive activities, customer or supplier activities, and the regulatory and political climates of the educational environment (Heath, 1996:2).

The reasons why tertiary educational institutions need competitive intelligence now more than ever are multiple (Kahaner, 1996:28):

- Firstly, the pace of daily business is increasing rapidly, as can be seen in the extensive use of fax machines, e-mail and overnight delivery services over the traditional mailing services. Suddenly, projects that took weeks must be accomplished in days.

- Secondly, there is an information overload, causing institutional executives to have to wade through excessive amounts of articles, e-mails, and journals in order to obtain that which they require for business decisions. Information in itself is not power, but the analysis and filtering thereof is. As stated by Kahaner (1996:29), 'the only thing worse than having too little information is having too much information.'

- Thirdly, the world is faced with a global economy, as companies no longer think in terms of political borders. For instance, improved telecommunication technology has enabled financial firms to locate anywhere in the world, global banking to become commonplace, and distance and telematic learning to proliferate. This, in turn, leads to increased global competition from new competitors, which competitive intelligence can help identify (Kahaner, 1996:30).

- Existing competition in the educational field has also become more aggressive, increasing market share at the expense of their competitors. For instance, many institutions, in the fight for students, will sacrifice profits for market share. Competitive intelligence can help forecast competitor's actions, thus allowing the institution to become proactive.

- In addition, political changes, like never before in history, affect business quickly and forcefully. For example, the crumbling of the Berlin Wall and the unbanning of the ANC created new players and new markets overnight. Kahaner (1996:31) claims that competitive intelligence can keep one informed of such political changes that affect one's business.

- Rapid technological change, especially in the computer industry, is dramatically changing the face of business. These technological breakthroughs can mean new opportunities. Keeping track, therefore, of technological changes in one's own industry and other industries is vital for survival, claims Kahaner (1996:31).

In addition to the abovementioned reasons, McGonagle and Vella (1996:41-42) argue convincingly that competitive intelligence usually becomes important when the organisation faces any of the following threats:

- Competition increases from institutions and organisations outside the industry's traditional technological and regulatory boundaries;

- competition increases, both actual and potential, from institutions based outside the home country;

- clients become increasingly sophisticated and knowledgeable, demanding more and openly comparing services and sources; and 
- changes occur continuously in the nature and variety of services to continue competing.

From the current educational situation it is rather obvious that tertiary institutions indeed experience these threats and are in need of competitive intelligence. Competitive intelligence, according to Combs and Moorhead (1992), is the tool enabling companies to perceive their threats and provide ways of obtaining the necessary information in order to counteract them. According to tradition, Frederick the Great said (as cited in Combs \& Moorhead, 1992): 'It is pardonable to be defeated, but never to be surprised'. The real value of competitive intelligence, according to Johnson, (1998b) is to provide managers with the organisational tool to learn what the competitor will do, not what the competitor has already done.

The bottom line benefits of competitive intelligence according to Johnson (1998b) are improved market and environmental knowledge, improved cross-functional relationships in the organisation, greater confidence in making strategic plans, and improvements in product and service quality versus the competition. Calof (1998) states that the value of competitive intelligence can also be defined in terms of the areas of the organisation that can best benefit from it. It has immense value for human resources, production, research and development, the development of new strategies and marketing. To this list can also be added tertiary education.

\section{Using the WWW as instrument for competitive intelligence}

Although there are many sources of competitive intelligence, this paper will focus on the value of the WWW as source of competitive intelligence. The world is going through pervasive change and the adoption of the Internet as the infrastructure and conduit enables people to live and do business differently. The use of Web-enabled competitive intelligence tools is therefore seen as the next major business benefit to be delivered by the Internet (Pecker, 1998:31). The WWW is probably one of the most important elements of any organisation's competitive intelligence programme and is growing in popularity among organisations (Kahaner, 1996:70).

Major advantages of the WWW is its speed, ease of use and the low cost of information acquisition. It is relatively easy and cheap to follow special alert-type Web sites, monitor competitors' Web sites, and skim newsgroup information. An important disadvantage on the other hand is that the reliability of the information is not always known.

To companies and tertiary educational institutions, competitive intelligence on the WWW is often as good a reason to establish a Web presence as are concerns for image or dreams of an on-line world-wide learner market. In the new telematic or distance learning educational setup, the main competitor may be located on the other side of the world, and it would be essential to know about every move that he makes. The tool used for this purpose is competitive intelligence.

Competitive intelligence on the WWW can be divided into four categories, namely technological change, competitors, marketing, and societal trends. A good place to start with competitive intelligence, however, is the Web sites of competitors. Ironically, much of the most useful information is provided by the competitors. It should also be borne in mind that students remain a valuable source for information about competitors, clients, courses, and 
strategy.

The following model, consisting of various competitive intelligence activities, was developed for the tertiary educational environment:

Table 1 Scope of competitive activities in the tertiary educational environment

\begin{tabular}{|c|c|c|}
\hline Financial & Course development & Research \\
\hline $\begin{array}{l}\text { Departmental or school } \\
\text { budgets/forecasts }\end{array}$ & Outsourcing strategies & Research budgets \\
\hline Earnings and revenues & $\begin{array}{l}\text { Academic quality } \\
\text { assurance programmes }\end{array}$ & Focus areas \\
\hline Non-public financials & Development cycle times & New product plans \\
\hline $\begin{array}{l}\text { Capital investment } \\
\text { strategies }\end{array}$ & Content of courses & Development efforts \\
\hline Capital expenditures & Emphasis of courses & \\
\hline Debt & $\begin{array}{l}\text { Specifics about } \\
\text { educational goals and the } \\
\text { strategies to achieve them }\end{array}$ & \\
\hline Funding & $\begin{array}{l}\text { Module outlines and } \\
\text { overviews }\end{array}$ & \\
\hline Competitors & Alliances & Information systems \\
\hline Client base & Academic alliances & Applications \\
\hline Programmes offered & Joint ventures & Communications networks \\
\hline Courses offered & Organisational impact & $\begin{array}{l}\text { System and network } \\
\text { integration }\end{array}$ \\
\hline Curricula & Market impact & Investment focus \\
\hline $\begin{array}{l}\text { Detailed pricing } \\
\text { information } \\
\end{array}$ & Partnerships & Technology - cutting-edge \\
\hline Threats & & $\begin{array}{l}\text { Incorporation of } \\
\text { technology into instruction }\end{array}$ \\
\hline Marketing & Service & Corporate structures \\
\hline $\begin{array}{l}\text { Advertising and promotion } \\
\text { budgets }\end{array}$ & Methods of distribution & $\begin{array}{l}\text { Detailed organisational } \\
\text { charts }\end{array}$ \\
\hline Service cost and margins & Service territories & Organisational structures \\
\hline Pricing strategies & $\begin{array}{l}\text { Service revenue and } \\
\text { volume }\end{array}$ & $\begin{array}{l}\text { Corporate and divisional } \\
\text { interaction }\end{array}$ \\
\hline Academic centres & Top programmes & $\begin{array}{l}\text { Management profiles and } \\
\text { depth }\end{array}$ \\
\hline Programme strategies & Key corporate clients & $\begin{array}{l}\text { Biographical information } \\
\text { about top management }\end{array}$ \\
\hline Organisation image & Target markets & $\begin{array}{l}\text { Personalities of decision } \\
\text { makers }\end{array}$ \\
\hline Name recognition & Market share & Affiliations \\
\hline Positive perception & Quality & Re-engineering strategies \\
\hline $\begin{array}{l}\text { Comprehensive } \\
\text { information about } \\
\text { educational locations, } \\
\text { offices, and service centres }\end{array}$ & & Compensation reviews \\
\hline Environment changes & & Motivation of workforce \\
\hline Annual reports & & $\begin{array}{l}\text { Faculty lists - } \\
\text { qualifications; interests }\end{array}$ \\
\hline
\end{tabular}


Obviously this information should be approached from a strategic, tactical and counter intelligence perspective (Johnson, 1998).

With the arrival of information technology, almost everyone has access to the same information, which then renders the information itself less valuable than before. The competitive advantage therefore lies in the creative processing, analysing and filtering of the raw information into usable and meaningful intelligence according to normal competitive intelligence processes and the competitive intelligence cycle (Kahaner, 1996:21-22; Calof, 1998).

\section{Sources of competitive intelligence on the WWW}

The Internet, and more specifically the WWW, consists of a tremendous collection of elements that can be used as possible sources of competitive intelligence, for example:

- discussion groups, which allow exchanges of messages and information among people with the same interests;

- informal 'chat' groups;

- computer sites, run by universities and other organisations, which allow remote searching for materials and references on a wide variety of subjects;

- 'home pages' on the WWW. These are collections of information on a particular institution or subject, often including hypertext links to other sites of interest. Corporate home pages can include information ranging from portions of an annual report to catalogues of products and services, and from online press releases to job postings (McGonagle \& Vella, 1996:116);

- electronic bulletin and notice boards;

- virtual libraries (Fuld, 1995:156-157);

- newsgroups or listservs (Kahaner, 1996:75);

- timetables;

- interactive electronic feedback pages;

- lecture notes and learning support material;

- past examination papers;

- practice questions;

- computer aided learning (CAL) information (Sosabowski, et al., 1998:194);

- alumni newsletters;

- government regulations;

- Web sites, which provide information on a magnitude of tertiary institutions and carry links to financials, operating information, and lists of competitors;

- electronic tertiary educational journals that contain course, curricula, job functions, affiliations, geography;

- government sources, which are searchable archives providing invaluable insights into the current and future activities of tertiary institutions;

- annual reports containing self-portraits of the institution;

- other search engines that lead to press releases, course reviews, or job listings;

- breaking news sources, that provide institution-related daily news, and executive summaries, for example www.barney.co.za;

- press releases issued by institutions, for example www.e-data.co.za;

- local newspapers, which often cover aspects of an institution that a larger publication 
might overlook; and

- conference information, often an important venue for institutions to make programme or strategy announcements.

\section{Practical example}

The management education industry experienced four forces that changed the environment in which business schools operate, namely:

- Global, technological and market changes with increased pressure on the relevancy of curricula, course material, operating practices and teaching models (Strasheim, 1998:3$6)$;

- increased competition amongst local business schools, as well as competition from foreign universities (Bisschoff \& Bischoff, 1997:1; Bisschoff \& Bischoff, 1999:1; Strasheim, 1998:3-6);

- market pressures to drop standards due to deficiencies in the former education system of disadvantaged communities, as well as the new Employment Equity Act of 1998 (Strasheim, 1998:3-6); and

- a new higher education system introduced by the government (Strasheim, 1998:3-6).

Owing to these changes an important question is always whether MBA programmes meet the needs of business practice, especially in South Africa where economic development and productivity growth are being jeopardised by the shortage of skilled and high-level managerial human resources (Louw et al., 1998:1-3).

Based on a few decades of presenting a contact MBA, the Potchefstroom University started with a telematic MBA in 1997 with 653 students (Bisschoff, 1997:2-3). The problem however was that the contact and telematic programmes differed extensively with regard to core courses, entry qualifications, and strategy. Another complicating factor was the increased competition from international business schools, which meant that to sustain a competitive advantage, the MBA should be internationally compatible with an indigenous South African uniqueness. The Potchefstroom Business School also decided on a new focus, namely to change managers and unlock their potential to enable them to create value and make a difference within their organisations and to meet global challenges.

Owing to these issues, it was decided to fundamentally restructure the MBA programme, courses and content. Therefore all the business schools at South African Universities (including RAU which technically is not a business school), as well as the best business schools in the United States of America and Europe, were investigated with regard to their courses and syllabi. The objective was to use competitive intelligence to:

- establish the core courses of the MBA;

- determine the course content;

- assess the relative importance of skills development; and

- establish specific outcomes of the MBA programme.

The following business schools were visited by using the WWW:

Table 2 Business schools visited via the WWW

\begin{tabular}{|l|l|l|}
\hline $\begin{array}{l}\text { South African Business } \\
\text { Schools }\end{array}$ & $\begin{array}{l}\text { American Business } \\
\text { Schools }\end{array}$ & $\begin{array}{l}\text { European Business } \\
\text { Schools }\end{array}$ \\
\hline
\end{tabular}




\begin{tabular}{|c|c|c|}
\hline University of Pretoria & Harvard University (MA) & INSEAD (France) \\
\hline University of South Africa & Stanford University (CA) & NIMBAS (Netherlands) \\
\hline University of Stellenbosch & Columbia University (NY) & $\begin{array}{l}\text { EAP European School for } \\
\text { Management (France) }\end{array}$ \\
\hline $\begin{array}{l}\text { University of the } \\
\text { Witwatersrand }\end{array}$ & $\begin{array}{l}\text { Massuchusets Institute of } \\
\text { Technology Sloan School } \\
\text { of Management (MA) }\end{array}$ & ESC Rouen (France) \\
\hline University of Cape Town & $\begin{array}{l}\text { University of Pennsylvania } \\
\text { - Wharton (Pen) }\end{array}$ & $\begin{array}{l}\text { IESE - University of } \\
\text { Navarra (Spain) }\end{array}$ \\
\hline $\begin{array}{l}\text { University of Durban } \\
\text { Westville }\end{array}$ & \begin{tabular}{|l|} 
Northwestern University - \\
Kelogg (Il)
\end{tabular} & $\begin{array}{l}\text { HEC School of } \\
\text { Management (France) }\end{array}$ \\
\hline $\begin{array}{l}\text { Milpark Business School - } \\
\text { Midrand campus }\end{array}$ & University of Chicago & $\begin{array}{l}\text { HEC ISA (France and } \\
\text { Switzerland) }\end{array}$ \\
\hline \multirow[t]{2}{*}{$\begin{array}{l}\text { Rand Afrikaans University } \\
\text { (M.Com) }\end{array}$} & $\begin{array}{l}\text { Dartmouth College - Tuck } \\
(\mathrm{NH})\end{array}$ & $\begin{array}{l}\text { Nijenrode Unviersity } \\
\text { (Netherlands) }\end{array}$ \\
\hline & $\begin{array}{l}\text { University of California, } \\
\text { Riverside - A. Gary } \\
\text { Anderson }\end{array}$ & $\begin{array}{l}\text { SDA University of } \\
\text { Bocconi (Italy) }\end{array}$ \\
\hline Other & $\begin{array}{l}\text { Duke University - Fuqua } \\
\text { (NC) }\end{array}$ & ESADE (Spain) \\
\hline \multirow[t]{14}{*}{$\begin{array}{l}\text { University of Western } \\
\text { Australia (Australia) } \\
\end{array}$} & $\begin{array}{l}\text { University of California - } \\
\text { Berkely (Haas) }\end{array}$ & $\begin{array}{l}\text { Open University Business } \\
\text { School (United Kingdom) }\end{array}$ \\
\hline & $\begin{array}{l}\text { University of Michigan - } \\
\text { Ann Arbor }\end{array}$ & $\begin{array}{l}\text { Herriot-Watt - Edinburgh } \\
\text { Business School (United } \\
\text { Kingdom) }\end{array}$ \\
\hline & $\begin{array}{l}\text { University of Virginia - } \\
\text { Darden }\end{array}$ & $\begin{array}{l}\text { University of Stirling } \\
\text { (United Kingdom) }\end{array}$ \\
\hline & $\begin{array}{l}\text { New York University - } \\
\text { Stern }\end{array}$ & $\begin{array}{l}\text { University of Bath (United } \\
\text { Kingdom) }\end{array}$ \\
\hline & $\begin{array}{l}\text { Carnegie Mellon } \\
\text { University (PA) } \\
\end{array}$ & $\begin{array}{l}\text { Birmingham Business } \\
\text { School (United Kingdom) }\end{array}$ \\
\hline & $\begin{array}{l}\text { University of North } \\
\text { Carolina - Chapel Hill - } \\
\text { Kenan-Flagler }\end{array}$ & $\begin{array}{l}\text { City University Business } \\
\text { School (United Kingdom) }\end{array}$ \\
\hline & $\begin{array}{l}\text { Cornell University - } \\
\text { Johnson Graduate School } \\
\text { of Management (NY) }\end{array}$ & $\begin{array}{l}\text { International Institute for } \\
\text { Management Development } \\
\text { (IMD) (Switzerland) }\end{array}$ \\
\hline & Yale University (CT) & $\begin{array}{l}\text { Rotterdam School of } \\
\text { Management (Netherlands) }\end{array}$ \\
\hline & $\begin{array}{l}\text { University of Texas: Texas } \\
\text { Business School - Austin }\end{array}$ & $\begin{array}{l}\text { London Business School } \\
\text { (United Kingdom) }\end{array}$ \\
\hline & $\begin{array}{l}\text { University of Rochester - } \\
\text { William E. Simon (NY) }\end{array}$ & $\begin{array}{l}\text { Henley Management } \\
\text { College (United Kingdom) }\end{array}$ \\
\hline & Mississipi State University & $\begin{array}{l}\text { Norwegian School of } \\
\text { Management BI Stiftelsen } \\
\text { (Norway) }\end{array}$ \\
\hline & $\begin{array}{l}\text { University of Arizona - } \\
\text { Eller (Ar) }\end{array}$ & $\begin{array}{l}\text { University of Wales } \\
\text { (United Kingdom) }\end{array}$ \\
\hline & \begin{tabular}{|l|} 
University of Minnesota - \\
Carlson
\end{tabular} & $\begin{array}{l}\text { De Montford University } \\
\text { (United Kingdom) }\end{array}$ \\
\hline & & $\begin{array}{l}\text { University of Jönköping - } \\
\text { Jönköping International }\end{array}$ \\
\hline
\end{tabular}




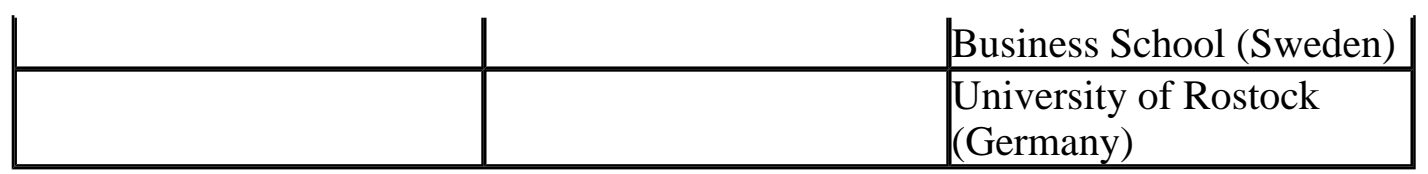

By studying these business schools, ten core courses, which usually form the basis of courses offered in the MBA programme, were identified. A further five courses that featured internationally and are of importance in South Africa were added. The result correlated well with the findings of the study of Louw et al. (1998) which was conducted amongst 633 MBA graduates regarding business needs. The results were as follows:

Table 3 Core courses

\begin{tabular}{|l|l|}
\hline Financial & Human resources \\
\hline Financial management & \\
\hline Management and financial accounting & Organisational behaviour \\
\hline Business management & General \\
\hline General management & Management economics \\
\hline Marketing management & Management statistics \\
\hline Production or operations management & \\
\hline Strategic management & \\
\hline
\end{tabular}

(Also, compare Louw et al., 1998:13-16 for comparative research findings in South Africa.)

During the investigation the following courses were found to be electives:

- Information management

- Labour relations management

- Entrepreneurship

- Technology management

- Business law

- International management.

After studying local and international tendencies, focuses, core courses and syllabi, it was decided to restructure the MBA as follows:

Table 4 Content of the MBA

\begin{tabular}{|l|l|l|}
\hline Year 1 & Year 2 & Year 3 \\
\hline First semester & First semester & First semester \\
\hline General management & Management accounting & Strategic management \\
\hline Financial accounting & Production management & Entrepreneurship \\
\hline Organisational behaviour & Technology management & Change management \\
\hline Second semester & Second semester & Second semester \\
\hline Management statistics & Marketing management & Dissertation or \\
\hline Management economics & Financial management & Management report or \\
\hline Information management & Labour relations management & Strategic thinking project \\
\hline
\end{tabular}

The main intention with the restructuring of the MBA programme was to be on par with international business schools with regard to core courses and focus, but to maintain a specific South African approach due to the unique needs of the educational situation. 


\section{Conclusions and recommendations}

The substance of the future is largely shaped by today's decisions based on relevant information. However, we are not living in the age of information anymore, but in the age of intelligence. By using competitive intelligence tertiary institutions can thus:

- Anticipate changes in the educational marketplace;

- anticipate actions of competitors;

- discover new or potential competitors;

- learn from the successes and failures of other educational institutions;

- learn about new technologies, services, and processes that affect the institution;

- learn about political, legislative, or regulatory changes that can affect the institution;

- enter new programmes;

- look at the own business practices against the background of new ideas and concepts; and

- implement the latest management tools (Kahaner, 1996:22-27).

To position itself as a leading-edge educational institution in the turbulent educational environment, it is necessary for a tertiary educational institution to use the World Wide Web as instrument for competitive intelligence.

'If a little knowledge is dangerous, where is the man who has so much to be out of danger.'

Thomas Henry Huxley

Top

\section{References}

Basson, J.F., Bisschoff, A. \& Fourie, L.C.H. 1999. Ondersoek na die gehalte van telematiese MBA aansoekers vir 1999. Potchefstroom: PBS. 14 p.

Bisschoff, A. 1997. Jaarverslag 1996: Magister in bedryfsadministrasie (Telematies).

Potchefstroom: TLS. 9 p.

Bisschoff, A. \& Bisschoff, C.A. 1997. 'n Omvattende ondersoek na kliëntediens van die telematiese program. PU vir CHO: TLS Research Papers, 97/1. 44 p.

Bisschoff, A. \& Bisschoff, C.A. 1999. 'n Omvattende ondersoek na kliëntediens van die telematiese MBA program. PU vir CHO: TLS Research Papers, 99/2. 32 p.

Calof, J. 1998. What is one's competitive intelligence quotient (C IQ)? Nov. 17. Available on Internet: http://strategis.ic.gc.ca/ssg/mi04122e.html [Date of use: Aug. 27, 1999].

Combs, R.E. and Moorhead, J.D. 1992. The competitive intelligence handbook. Metuchen, MJ: Scarecrow press. Available on Internet: http://www.combsinc.com/chapt1.htm [Date of use: Aug. 27, 1999].

De Wet, J.M. 1999. The use of competitive intelligence sources and methods as an aid in the selection of stock market shares. Potchefstroom: PU vir CHO. (Dissertation - MBA)

Fuld, L. 1985. Competitor intelligence: How to get it; How to use it. New York: Wiley. Fuld, L. 1995. The new competitor intelligence: The complete resource for finding, analyzing, and using information about one's competitors. New York: Wiley. 482 p.

Gilad, B. 1994. Business blindspots. Chicago: Probus.

Greyling. C. 1999. The changing education environment in S.A. Johannesburg: ABSA. 10 p. Hannon, J.M. 1997. The nexus between human resource management and competitive intelligence: An international perspective. Management international review, Special issue 1997(1): 65-84.

Heath, R.P. 1996. The competitive edge. Marketing tools magazine. Sept. Available on 
Internet: http://www.demographics.com/publications/mt/96_mt/9609_mt/9609mf02.htm. [Date of use: Aug. 27, 1999].

Johnson, A.R. 1998. An introduction to knowledge management as a framework for competitive intelligence. (In: Aurora, W.D.C. A white-paper for presentation at the international knowledge management executive summit in San Diego California in June 1998. Available on Internet: http://www.aurorawdc.com/ekma.htm. [Date of use: Aug. 27, 1999]).

Johnson, A.R., 1998a. On predicting the future: Competitive intelligence as a knowledge management discipline. Available on Internet: http://www.aurorawdc.com/kmworld1.htm. [Date of use: Aug. 27, 1999].

Johnson, A.R., 1998b. What is competitive intelligence? Available on Internet: http://www.aurorawdc.com/whatisci.htm. [Date of use: Aug. 27, 1999].

Kahaner, L . 1996. Competitive intelligence: From black ops to boardrooms - How businesses gather, analyze, and use information to succeed in the global marketplace. New York: Simon \& Schuster. 300 p.

Louw, L., Bosch, J.K. \& Venter, D.J.L. 1998. Graduate perceptions on the status and nature of South African MBA programmes, Centre for applied business management, Research report. Port Elizabeth: UPE. 37 p.

McGonagle, J.J. \& Vella, C.M. 1996. A new archetype for competitive intelligence.

Westport: Quorum. 225 p.

Pecker, R. 1998. Business intelligence market booming, Computing S.A., :31, October 26. RSA 1995. No. 58 of 1995: South African qualifications authority act, Government gazette vol. 364, no. 16725, 4 October 1995. 11 p.

RSA 1998a. No. 55 of 1998: Employment equity act, Government gazette, vol. 400, no. 19370, 19 October 1998. 55 p.

RSA 1998b. No. 97 of 1998: Skills development act, Government gazette, vol. 401, no. 19420, 2 November, 1998. 45 p.

RSA 1998c. No. 98 of 1998: Further education and training act, Government gazette, vol. 401, no. 19421, 2 November 1998. 39 p.

Sherman, C. 1998. Competitive Intelligence on the Web. (In: About.com: Human guides:

Human interests: Web search. Available on Internet: http://websearch.miningco.com/library/ weekly/aa081498.htm. [Date of use: Aug. 27, 1999]).

Sosabowski, M.H., Herson, K., \& Lloyd, A.W. 1998. Enhancing first-year undergraduate chemistry teaching and learning quality - application of intranet-based resources. South African Journal of Chemistry, 51(4):193-199.

Strasheim, C. 1998. Product and service quality in management education. Johannesburg: University of the Witwatersrand. (Special Report based on MBA dissertation). 49 p. Venkatraman, N. \& Henderson, J.C. 1998. Real strategies for virtual organizing. Sloan Management Review, (Fall):33-48.

\section{Disclaimer}

Articles published in SAJIM are the opinions of the authors and do not necessarily reflect the opinion of the Editor, Board, Publisher, Webmaster or the Rand Afrikaans University. The user hereby waives any claim he/she/they may have or acquire against the publisher, its suppliers, licensees and sub licensees and indemnifies all said persons from any claims, lawsuits, proceedings, costs, special, incidental, consequential or indirect damages, including damages for loss of profits, loss of business or downtime arising out of or relating to the user's use of the Website. 
ISSN 1560-683X

Published by InterWord Communications for the Centre for Research in Web-based Applications, Rand Afrikaans University 